\title{
Notes on the Early Stages of two Polychaetes, Nephthys hombergi Lamarck and Pectinaria koreni Malmgren.
}

\author{
By \\ Douglas P. Wilson, M.Sc., \\ Naturalist at the Plymouth Laboratory.
}

With 3 Figures in the Text.

\section{PART I}

\section{Nephthys hombergi Lamarck}

Trochospheres of Nephthys hombergi Lamarck are readily obtainable at Plymouth when the adult worms are mature from June to September. The worms are dug out of the muddy sand on the lower regions of the shore, and their eggs and sperms obtained by slitting open the body cavity. Fertilizations are easily made in glass finger-bowls of clean sea-water. Although apparently ripe worms have been kept under sea-water circulation in the laboratory, and under a variety of conditions, none has ever been induced to spawn naturally. After some days the body walls of some individuals have split along the back and shed their genital products in that way; these, however, were probably unhealthy and abnormal. A high percentage of the eggs got by cutting open the worms have fertilized and given rise to cultures of strongly swimming larvæ. During the summers of 1932-34 much time and effort were expended in numerous attempts to rear these larvæ, but in no single instance was success obtained. It had been hoped to collect material for a detailed histological study of the development, for it may be of a straightforward and simple type that would throw light on various problems of Polychæte embryology. Although these hopes have not been realized it seems of value to describe the trochosphere of which no entirely satisfactory account exists, in spite of a few references to it by previous writers.

claparède and Mecznikow (1868) seem to have been the first to have identified trochospheres and later larvæ from the plankton as those of Nephthys. They appear to have been guided in their identification mainly by the form of the bristles of their later stages, which closely resembled those of the adults of this genus. Fewkes (1885) following their identification described stages from what was apparently an allied species in the plankton at Newport, Rhode Island, U.S.A. He reared the larvæ 
from the trochosphere to a stage with about ten chætigers. He admitted that the identification was provisional until either the earliest stages were traced back to the parent, or the latest was reared into the adult. Häcker (1896 and 1898) and Leschke (1903) obtained from the plankton segmented larvæ which they referred to this genus, largely, so it seems, on the basis of the earlier papers. McIntosh (1908) followed suit with figures of three fairly late stages and gave an account of the history to date. Gravely (1909) also accepted the identifications of previous workers and described segmented Nephthys larvæ from the Port Erin plankton.

While it is likely that all these authors have quite correctly assigned their larvæ to the genus Nephthys-some of them have even been so bold as to name the species-final proof can only be obtained in the manner already indicated by Fewkes. A step in this direction was taken by Fuchs (1911) who, in the Plymouth Laboratory, made fertilizations of Nephthys hombergi collected from the same sandy bays as those from which my material has been derived. His larvæ, however, like mine, ceased to develop after about fourteen days, although they could be kept alive for a week or more longer. His did not feed although provided with cultures of diatoms and other algæ; mine, on the other hand, ate Nitzschia and Thalassiosira and probably other organisms as well. Fuchs' description and figures of his trochospheres were a big advance on anything done previously, but they lack certain interesting details and no indication of size is given. Only in broad outlines could they be said to agree with the Nephthys trochospheres of Claparède and Mecznikow and of Fewkes. The same remark applies when my drawings and description are compared.

\section{Description of the Eggs and Trochospheres.}

The eggs are spherical or almost so, finely granular and opaque; by reflected light the colour is pink. They are about $112 \mu$ in diameter and are surrounded by a membrane 1.5-2 $\mu$ thick. After fertilization this membrane separates slightly from the egg and the polar bodies are then produced.

Twelve to sixteen hours after fertilization the larvæ begin to swim. In shape they are spherical with an apical tuft of long cilia at the anterior end and a prototrochal band of beating cilia round the equator. The cilia pass through the egg membrane that from now on forms the cuticle of the larva. The cells of the latter are crowded with oily-looking globules, and there is a certain amount of dark brown pigment scattered irregularly over the body. The larvæ are soon swimming forwards at a relatively rapid rate and rotating on their longitudinal axes.

After two or three days the long apical cilia disappear and their place 
is taken by shorter but more numerous cilia that cover a much larger area at the anterior end (see Fig. 1). The prototroch completely encircles the body a little behind the equator. It consists of three bands, the middle one being the broadest and carrying the longest cilia, while the anterior band is the narrowest and bears the shortest cilia. These three bands are all very close together. In front of the prototroch and situated rather ventrally there is on each side a small curved line of beating cilia, with what appears to be a slight depression immediately anterior to it. Posterior to the prototroch, but on the left side only, there is a curious

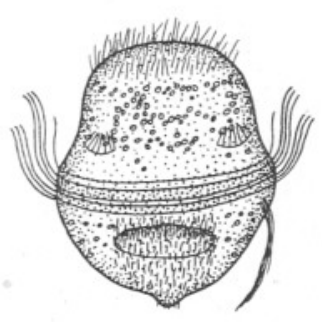

A

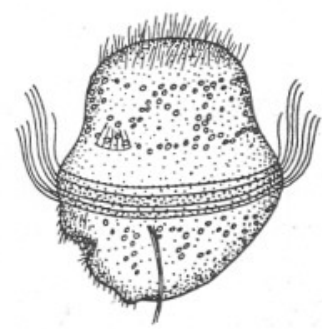

B

FIG. 1.-Drawings from life, $\times 156$, of a four-days-old trochosphere of Nephthys hombergi Lamarck. A, ventral view; B, view of left side. Actual length, excluding apical cilia, approximately $167 \mu$.

long tuft (sensory ?) composed of several cilia loosely fused together. Of the very many larvæ examined only two specimens had such a tuft on the right side as well as on the left, and one of these larvæ showed structural abnormalities. The mouth is rather large and wide, and is strongly ciliated. The cilia of the upper lip reach as far forward as the prototroch. From the posterior border of the mouth a very broad neurotroch leads back towards the anus. Just before the latter is reached this neurotroch abruptly narrows to pass over a slight prominence that rises immediately in front of the terminal anus.

The trochosphere is not very transparent; it has a pale yellow tint. Dark brown pigment specks are scattered irregularly over both hemispheres and are especially numerous under the prototroch. Refringent greenish yellow globules of varying size form a sort of irregular broad band round the episphere ; they are also present on the hyposphere where they sometimes form a band just behind the prototroch. These globules are close to the surface and often overlie the brown pigment specks. Globules of similar appearance occur deeper in the tissues, on the stomach wall, for example. The ectoderm is thick and apparently glandular. There are no bristles. The blastocoel is almost completely filled by the gut. The latter is well ciliated internally. 
Despite the fact that the larvæ were feeding and lived in plunger jars for fourteen days or more, they scarcely developed further. The prototroch appeared to split up into five or six rows of cilia instead of the original three, and the episphere and hyposphere walls became a little thinner. No other changes were observed.

\section{PART II}

\section{Pectinaria koreni Malmgren}

Very early larvæ of the Amphictenidæ have never been described, although late stages of Pectinaria, obtained from the plankton, have occasionally been illustrated and discussed (e.g. Gravely, 1909). This short note may therefore prove of some interest.

On 24th April, 1933, some specimens of Pectinaria koreni Malmgren were obtained when digging on the shore at Salcombe. When later, in the laboratory, they were removed from their tubes, they at once began

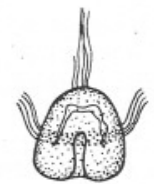

FIG, 2,-Gastrula of Pectinaria koreni about twenty-two hours after fertilization. Drawn from life, $\times 156$. Actual length, excluding apical cilia, approximately $58 \mu$.

to shed their genital products, a process that in the case of the females continued for several hours. Fertilizations were made, a good proportion of the eggs developing.

The eggs were very small; approximately $62 \mu$ in diameter. Each was closely invested in a transparent egg membrane that subsequently formed the cuticle of the larva. By reflected light the eggs were golden in colour, by transmitted light pale yellow; they were granular.

About sixteen hours after fertilization the embryos began to swim. They were almost perfectly spherical blastulæ with a tuft of long fine cilia at the apical end. A broad equatorial band of relatively long and very fine cilia formed the prototroch. The lower pole broadened and flattened, gastrulation taking place by invagination about twenty-two hours after fertilization. The gastrulæ (Fig. 2) swam rapidly forwards, rotating on their longitudinal axes. The limits of the blastocoel were irregular and not very distinct, but the archenteron was clearly defined. 
Figure 3 shows several views of a three-days-old trochosphere. For a Polychæte it was an unusually minute, although beautiful, larva. It was characterized by large ventrally produced lateral lips which, with the anterior lip bearing the prototroch, overhung the mouth in the form of a hood. These large lips are very characteristic of the later stages of Pectinaria. This trochosphere was quite transparent and of a yellowish colour by transmitted light. A few dark brown oily globules were scattered irregularly over the episphere. Very few, if any, were

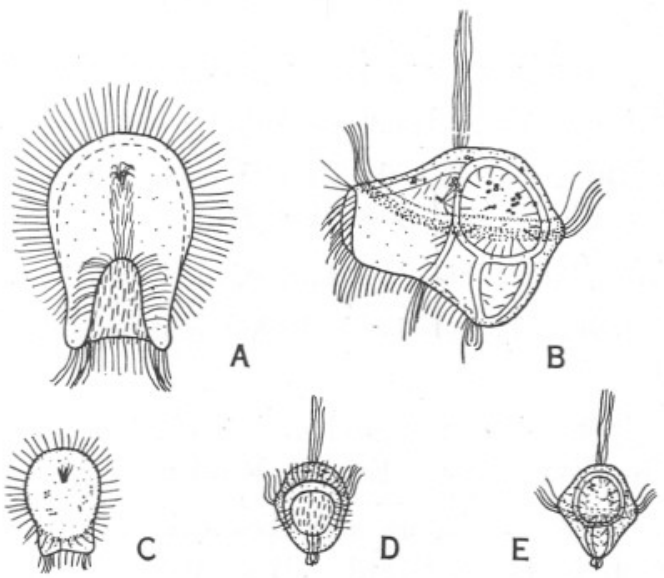

F1G. 3.-Sketches from life of a three-days-old trochosphere of Pectinaria koreni Malmgren. Actual length (apical plate to anus, excluding cilia) approximately $58 \mu$. A, view from below, $\times 312$; B, view of left side, $\times 312$; $\mathrm{C}$, view from above apical plate, $\times 156 ; \mathrm{D}$, morphologically ventral view, $\times 156 ; \mathrm{E}$, morphologically dorsal view, $\times 156$.

present on the hyposphere. The ciliation was very complicated and difficult to follow; the drawings must therefore to some extent be regarded as provisional. The long apical tuft was, however, conspicuous and the prototroch, raised on a slight ridge, was continuous all round. The prototroch consisted of two bands of cilia, a narrow anterior one and a broad posterior, with a distinct non-ciliated gap between. The lips were edged with long cilia, some of them apparently sensory. At the lower posterior corner of the mouth a tuft of long cilia was visible in lateral view (Fig. 3, B). From there a narrow neurotroch ran towards the anus. Just in front of the latter a tuft of curious curled, and nearly motionless, cilia probably belonged to the future functional telotroch. The gut was divided into œsophagus, stomach and intestine, all well ciliated internally. The mouth could be closed. The larva swam relatively fast in the direction of the apical cilia, sometimes rotating on its longitudinal axis, although not so rapidly as before. 
All attempts to rear these trochospheres failed. They were seen to have a few minute specks of food in their stomachs, but it seemed that diatoms were too large for them. They lived for a few days and then died.

\section{REFERENCES.}

Claparìde, E. and Mecznikow, E. 1868. Beiträge zur Kenntniss der Entwicklungsgeschichte der Chætopoden. Zeit. wiss. Zool., Bd. XIX.

Fewkes, W. J. 1885. On the Development of Certain Worm Larvæ. Bull. Mus. Comp. Zool., Harvard Coll., Camb., Mass. Vol. XI.

Fuchs, H. M. 1911. Note on the Early Larvæ of Nephthys and Glycera. Journ. Mar. Biol. Assoc., N.S., Vol. IX.

Gravely, F. H. 1909. Polychæt Larvæ. L.M.B.C. Memoir, XIX.

H“cker, V. 1896. Pelagische Polychätenlarven. Zeit. wiss. Zool., Bd. LXII.

HÂcker, V. 1898. Die pelagischen Polychæten-und Achætenlarven der Plankton-Expedition. Ergebn. Plankton-Exped., Bd. II, H.d.

Leschke, M. 1903. Beiträge zur Kenntniss der pelagischen Polychætenlarven der Kieler Föhrde. Wiss. Meer. Kiel., Bd. VII.

McIntosh, W. C. 1908. A Monograph of the British Marine Annelids. Vol. II, Pt. I. Ray Society. 